\title{
EXOGENOUS APPLICATION OF POLYAMINES IMPROVES GERMINATION AND EARLY SEEDLING GROWTH OF HOT PEPPER
}

\author{
Hammad Aziz Khan ${ }^{1 *}$, Khurram Ziaf ${ }^{2}$, Muhammad Amjad², and Qumer Iqbal ${ }^{2}$
}

\begin{abstract}
Polyamines are low molecular weight organic compounds involved in diverse range of biological processes in all living organisms. Seed priming is a technique that improves seed performance by rapid and uniform germination with normal and vigorous seedlings. A laboratory study was performed to explore the benefits of seed priming with polyamines on seed germination and seedling growth of hot pepper (Capsicum annuum L.) Hot pepper seeds were primed in aerated solution of putrescine, spermine, or spermidine $(25,50,75$, and $100 \mathrm{mM})$ for $48 \mathrm{~h}$ at $25 \pm 2{ }^{\circ} \mathrm{C}$. Significant results $(\mathrm{P}<0.05)$ were observed for different attributes of seed germination and early seedling growth. Polyamines priming resulted in earlier and synchronized germination via improving final germination percentage, time to $50 \%$ germination, mean germination time, germination energy, germination speed and germination index compared with control. Improvement in shoot and root length, seedling fresh and dry weight, seedling growth rate and seedling vigor index was clearly indicative of positive effects of seed priming with polyamines. Out of all polyamines, putrescine proved to be better at low concentrations (i.e. 25 and $50 \mathrm{mM}$ ) for most of the traits related to seed emergence and seedling growth.
\end{abstract}

Key words: Seed priming, Capsicum annuum, polyamines.

Q uality seed is the basis for agriculture production and for a better crop stand especially in case of vegetables. Vegetable growers need more uniformity and precise prediction of the emergence and crop stand (Pervez et al., 2009). Similarly, high yield of the vegetable crops can only be obtained with high stand establishment of seedlings so that they can compete with the environment and can produce best plantation (Grassbaugh and Bennett, 1998). Crops lacking a good stand show reduced efficacy of other agronomic practices and usually such inputs can never compensate for the negative impact of a poor stand. Obtaining healthy and vigorous seedlings, which can compete and withstand adverse abiotic and biotic stresses, is much more important. Rapid and uniform germination and emergence of seeds, normal and vigorous seedlings, are important determinants of successful stand establishment and ultimately increased yield and quality (Cantliffe, 2003). High quality seed is the basis for a durable and profitable agriculture and use of high-quality seed would ensure that seedlings emerge rapidly, tolerate adverse weather conditions, and resist diseases (Farooq et al., 2007).

${ }^{1}$ PMAS-Arid Agriculture University, Department of Horticulture, Rawalpindi 46300, Pakistan.

"Corresponding author (hazizkhan@yahoo.com).

${ }^{2}$ University of Agriculture, Institute of Horticultural Sciences, Faisalabad 38040, Pakistan.

Received: 18 January 2012.

Accepted: 8 July 2012.
Hot pepper (Capsicum annuum L.), commonly known as chili, is an important vegetable as well as spice crop of Pakistan. The yield of hot pepper is much lower in third world countries. One of the main causes for this poor yield is lack of a good stand establishment and reduced early growth as stressed by adverse environment. Germination and emergence of pepper seeds is often slow and non-uniform under normal as well as stress conditions (Wein, 1999; Demir and Okcu, 2004). Similarly, Andreoli and Khan (1999) found slow and erratic emergence and establishment of pepper seeds, especially under cool conditions. Pepper and tomato have non-starchy endosperm and this offered a mechanical barrier to the growing embryo resulting in poor germination (Andreoli and Khan, 1999). High germination and uniform stand establishment for chili pepper production is essential to maintaining profitable yields.

Improvement in stand establishment can be obtained by advancements in seed quality and seed enhancements, genetic improvement, as well as improved seeding techniques. Seed priming is a technique of seed enhancement that improves seed performance by rapid and uniform germination, normal and vigorous seedlings, which resulted in faster and higher rate of germination and emergence in different crops (Farooq et al., 2007; 2008), which also helps seedlings to grow in biotic or abiotic stress conditions (Ashraf and Foolad, 2005; Khan et al., 2009a; 2009b). Such seed treatments result in synchronized emergence and uniform stand establishment leading to improved yield. 
Seeds performance of many vegetables can be improved by inclusion of plant growth regulators during priming and other pre-sowing treatments (Ashraf and Foolad, 2005; Khan et al., 2009b). Polyamines (PAs) are small polycationic molecules found ubiquitously in all organisms. Their function has been reported in a variety of biological processes including transcription, RNA modification, protein synthesis and the modulation of enzyme activities (Takahashi and Kakehi, 2010). PAs are essential for growth, development, and cell differentiation in plants (Kusano et al., 2008). Moreover, PAs are also accumulated in plants and perform their function in plants under normal as well as stress conditions. Exogenous PAs may influence germination of isolated embryos depending on the type of polyamine, its concentration, and the state of the embryo dormancy (Farooq et al., 2011).

Some studies have shown the positive effects of PAs on seed germination, seedling vigor, growth and development of different crops when seeds were primed with PAs e.g. wheat (Iqbal and Ashraf, 2005; Farooq et al., 2011), sunflower (Farooq et al., 2007), rice (Farooq et al., 2008) and tomato (Afzal et al., 2009). Nonetheless, no study has been reported to evaluate the effects of polyamine seed priming on hot pepper. Therefore, the current study was proposed to assess benefits (if any) linked to seed priming with PAs on hot pepper through exploring responses at seed germination and early growth stages.

\section{MATERIALS AND METHODS}

The proposed study was conducted to determine the effect of seed priming treatments with PAs on emergence and seedling vigor of hot pepper cv. Hot Queen. Seeds of hot pepper 'Hot Queen' were obtained from Yousuf Seed Corporation Registered, Faisalabad, Pakistan. The initial seed moisture was $8.1 \%$ (dry weight basis).

\section{Priming treatment}

Seeds were surface sterilized by dipping in sodium hypochlorite $(5 \%)$ solution for $5 \mathrm{~min}$ and dried on filter paper. These surface sterilized seeds were primed in aerated solution of PAs (putrescine, spermidine, and spermine) each at concentrations of $25,50,75$, and 100 $\mathrm{mM}$, for $48 \mathrm{~h}$ at $25 \pm 2{ }^{\circ} \mathrm{C}$ under dark conditions. After priming treatment, seeds were washed with distilled water and dried at room temperature on filter paper in shade for $24 \mathrm{~h}$. Seeds were then packed in polythene bags and stored in a refrigerator $5 \pm 2{ }^{\circ} \mathrm{C}$ for further use.

\section{Germination test}

Primed and un-primed seeds (25 seeds per replicate) were germinated in Petri dish $(9 \mathrm{~cm})$ on double layer of Whatman $\mathrm{N}^{\circ} 1$ filter paper, moistened with distilled water. Petri dishes were placed at $25 \pm 2{ }^{\circ} \mathrm{C}$ under $16: 8 \mathrm{~h}$ photoperiod in an incubator (Farooq et al., 2008). The experiment was performed following completely randomized design with four replicates. Seeds with visible radicle were considered as germinated. Data were recorded daily for germination count following seedling evaluation protocol given in the handbook of the Association of Official Seed Analysis (AOSA, 1990).

Final germination percentage (FGP) was calculated at the end of experiment. Mean germination times (MGT) were calculated according to the equation of Ellis and Roberts (1981):

$$
M G T=\frac{\sum D n}{\sum n}
$$

where $n$ is the number of seeds germinated on day $D$, the number of days counted from the beginning of germination.

The time taken to $50 \%$ germination $\left(\mathrm{T}_{50}\right)$ was calculated according to the following modified formula by Farooq et al. (2005):

$$
T_{50}=t_{i}+\frac{\left(\frac{\mathrm{N}}{2}-n_{i}\right)\left(t_{j}-t_{i}\right)}{n_{j}-n_{i}}
$$

where $N$ is the final number of emerged seeds and $n_{i}, n_{j}$ are the cumulative number of seeds germinated by adjacent seed count at times $t_{i}$ and $t_{j}$ respectively, when $n_{i}<N / 2<n_{j}$.

Germination index (GI) was calculated according to the following formula given by Association of Official Seed Analysts (AOSA, 1983):

$\mathrm{GI}=\frac{\mathrm{N}^{\mathrm{o}} \text { of germinated seeds }}{\text { Days of first count }}+----+\frac{\mathrm{N}^{\mathrm{o}} \text { of germinated seeds }}{\text { Days of final count }}$

Germination speed (GS) was derived from the formula presented by Kotowski (1926). Germination energy (GE) was recorded on the $7^{\text {th }}$ day after planting. It is the percentage of germinating seeds $7 \mathrm{~d}$ after planting relative to the total number of seeds tested.

\section{Emergence test}

Primed and un-primed seeds (50 seeds per replicate) were sown in $20 \times 20 \mathrm{~cm}$ plastic trays filled with washed fine sand and irrigated with half-strength Hoagland's solution, kept at $25 \pm 2{ }^{\circ} \mathrm{C}$ under 16:8 h photoperiod in an incubator (Khan et al., 2009a). The experiment was performed following completely randomized design with four replicates.

Seedlings from each replicate were harvested randomly after $14 \mathrm{~d}$ of emergence and shoot and root length was measured from collar region with the help of measuring tape and averaged to obtain mean shoot and root length. Seedling fresh weight was recorded immediately after harvesting of seedlings from each replicate while dry weight was obtained by drying at $105^{\circ} \mathrm{C}$ for $24 \mathrm{~h}$ in oven (Khan et al., 2009b). Seedling growth rate (SGR) was calculated according to Amjad and Anjum (2002) while seedling vigor index (SVI) was calculated as suggested by Islam et al. (2009). 


\section{Statistical analysis}

Both experiments were repeated twice in completely randomized design. Data recorded for both the experiments were analyzed statistically using statistical software STATISTIX, and Least Significant Difference (LSD) test was performed at $5 \%$ probability level to compare the differences among treatment means.

\section{RESULTS}

Seed priming with PAs showed significant $(P \leq 0.05)$ results for seed germination and early growth of seedlings of hot pepper (Figures 1-5). All the seed treatments improved final germination percentage (FGP) as compared to control but no difference was observed among different treatments (Figure 1). Seed treatment with PAs decreased the MGT and time to reach $50 \%$ germination $\left(\mathrm{T}_{50}\right)$ compared with control, but putrescine (Put) showed the best results presenting no difference between different concentrations (Figure 1). Similarly, GI, GS, and GE were also enhanced by all treatments over un-treated seeds, with highest in case of Put treatment with no difference among its concentrations (Figure 2). Higher concentration $(100 \mathrm{mM})$ of spermine (Spm) had comparable results to Put while control showed significantly lower values.

All the seed treatments with PAs improved shoot length, root length, and root to shoot ratio of hot pepper seeds (Figure 3). Control showed significantly lowest values for shoot and root length, and root to shoot ratio compared with all other treatments. Most of treatment levels in different PAs were at par with each other but 50 $\mathrm{mM}$ concentration of all the PAs was better.
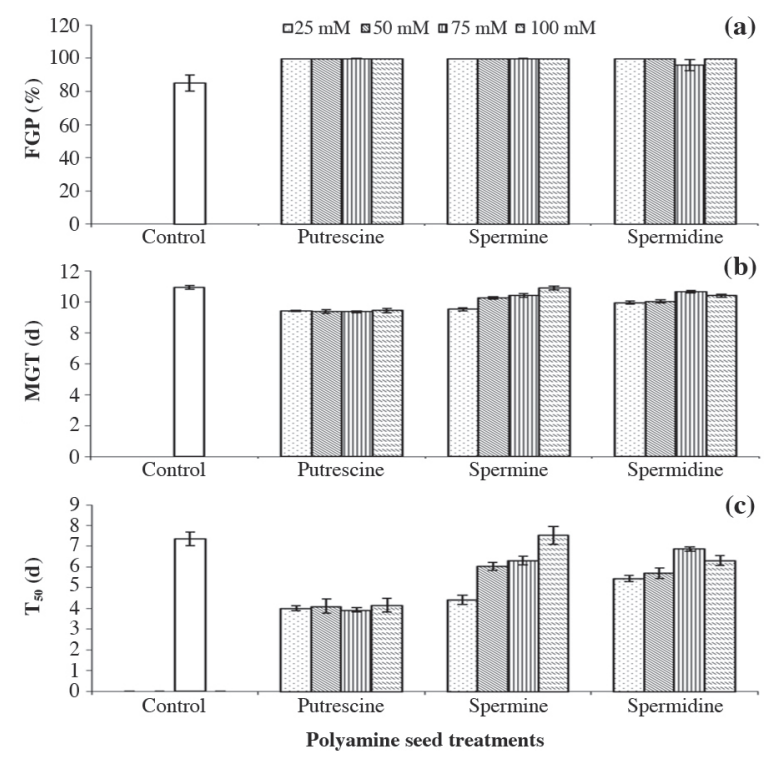

Figure 1. Effect of seed priming with polyamine on a) final germination percentage (FGP), b) mean germination time (MGT), and c) time to $50 \%$ germination $\left(T_{50}\right)$ in hot pepper (cv. Hot Queen).
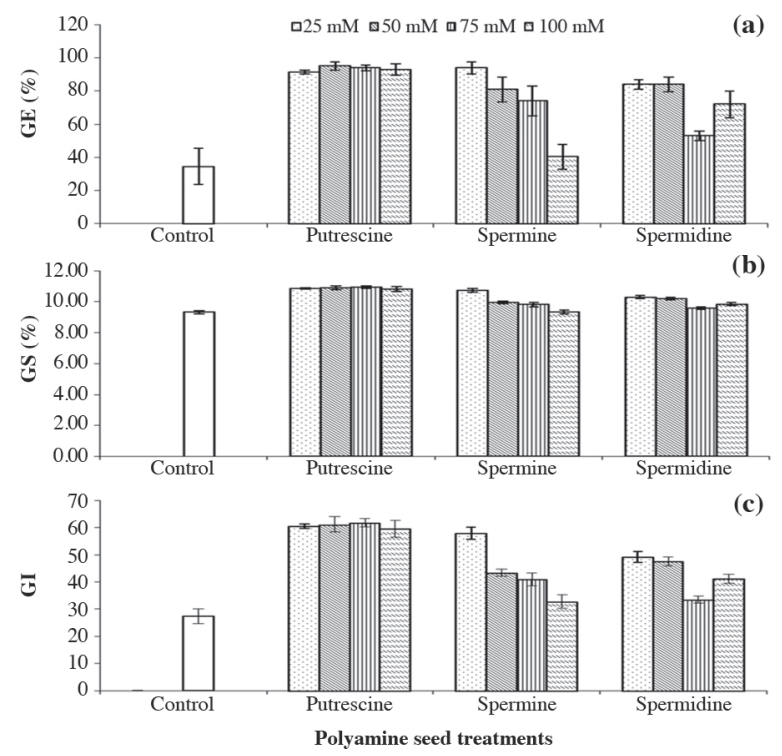

Figure 2. Effect of seed priming with polyamine on a) germination energy (GE), b) germination speed (GS), and c) germination index (GI) in hot pepper (cv. Hot Queen).
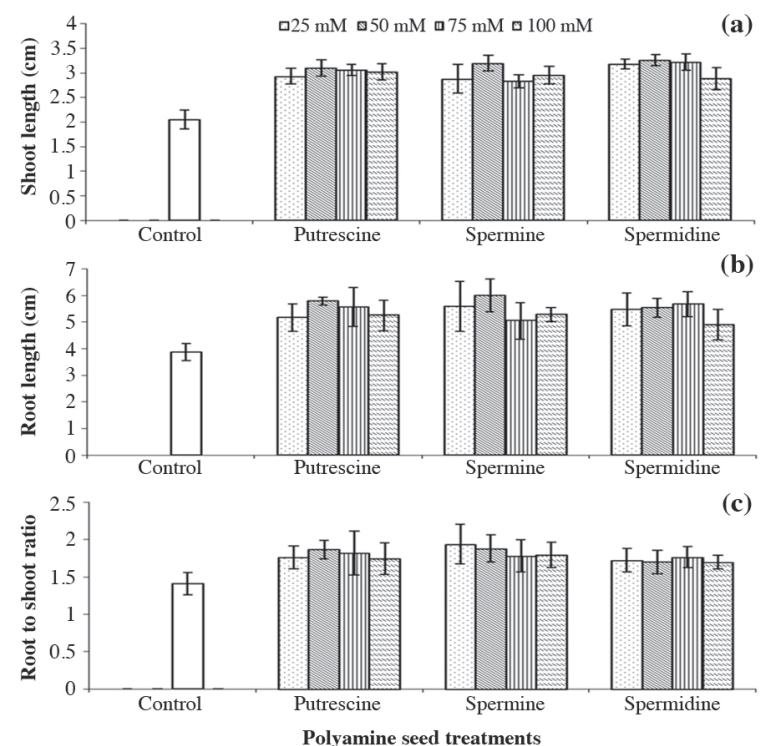

Figure 3. Effect of seed priming with polyamine on a) shoot length, b) root length, and c) root to shoot ratio in hot pepper (cv. Hot Queen).

Confirming above results, seeds pre-treated with all of PAs significantly $(P \leq 0.05)$ improved seedling fresh and dry weight as compared to untreated seeds. Maximum seedling fresh and dry weight was observed for seeds treated with Put followed by Spm and Spd having mixed behavior among different concentration (Figure 4). Likewise, SVI and SGR recorded high values as compared to control but more pronounced in SVI (Figure 5). All of the PAs exhibited almost same results for improvement in SVI and SGR with little variation among concentration levels. Maximum value for SVI was observed in $50 \mathrm{mM}$ Spm while for SGR in $50 \mathrm{mM}$ Spd (Figure 5). Overall, 


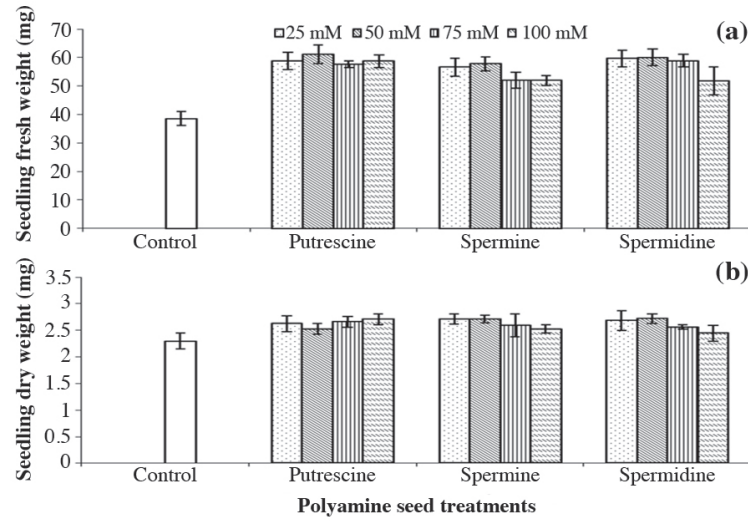

Figure 4. Effect of seed priming with polyamine on a) seedling fresh weight and b) seedling dry weight in hot pepper (cv. Hot Queen).
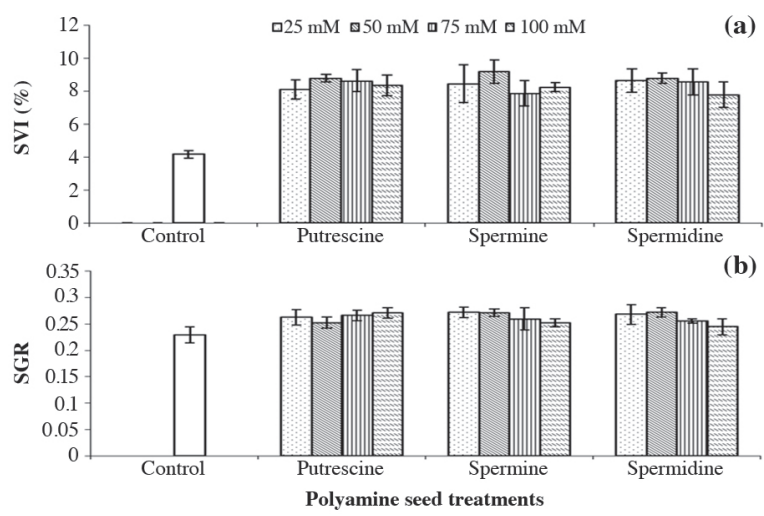

Figure 5. Effect of seed priming with polyamine on a) seedling vigor index (SVI), and b) seedling growth rate (SGR) in hot pepper (cv. Hot Queen).

lower concentrations of all PAs played their role in improving seed germination while mixed behavior was observed for seedling growth.

\section{DISCUSSION}

It could be concluded from the study that seed priming with PAs significantly enhanced the germination and early seedling growth of hot pepper compared to untreated seeds while this response was diverse for different PAs and their concentrations. Polyamines have tremendous potential to improve the early stand establishment of hot pepper crop. Earlier, it was observed that primed onion seeds had higher level of PAs as compared to control and there was positive correlation between seedling vigor and PAs level (Basra et al., 1994). This leads towards the hypothesis that seed priming increased the PAs level inside tissues which further improved the seed vigor and seedling growth. Enhanced germination and vigor of hot pepper seeds could be the result of enhanced metabolic activities (efficient mobilization and utilization of seed reserves and better genetic repair) (Srivastava, 2002; Farooq et al., 2008). These results are in line with the earlier findings (He et al., 2002; Farooq et al., 2007; 2008; 2011).
Seedling growth has also been improved by the seed priming with all PAs which in turn indicates invigorated seedling vigor. These results could be clearly observed through higher root and shoot length, seedling fresh and dry weights, SVI and SGR. Improvement in growth attributes might be the result of increased cell division within the apical meristem, causing augmented seedling growth (Huang and Villanueva, 1992; Farooq et al., 2008). Polyamines are key players in modulating cell division and its rate (Cvikrova et al., 1999). This indicates the importance of PAs in plant development which could be the reason behind performance of PAsin this study. During this study, all of the PAs stimulated the seed germination and seedling growth compared to control but Put was found more effective. Put at lower concentrations was found better as compared to other PAs, which confirms the results of Farooq et al. (2008) but contrast to the findings of Farooq et al. (2007) and Farooq et al. (2011).

\section{CONCLUSIONS}

It is concluded from the above results that although all polyamines (putrescine, spermine, or spermidine) promoted the earlier germination as well as synchronized it and imparted higher seedling vigor, putrescine performance was the best.

Aplicación exógena de poliaminas para mejorar la germinación y el crecimiento temprano de plántulas de ají. Las poliaminas son compuestos orgánicos de bajo peso molecular implicados en numerosos procesos biológicos en todos los organismos vivos. El acondicionamiento de semillas es una técnica que mejora el comportamiento de las semillas respecto a una germinación más rápida y uniforme, con plántulas normales y vigorosas. Se realizó un estudio de laboratorio para explorar los beneficios del acondicionamiento de semillas con poliaminas sobre la germinación y el crecimiento de plántulas de ají (Capsicum annuum L.) Las semillas de ají fueron colocadas en solución acuosa aireada de putrescina, espermina o espermidina $(25,50,75$ y $100 \mathrm{mM})$, durante $48 \mathrm{~h}$ a $25 \pm 2{ }^{\circ} \mathrm{C}$. Se observaron resultados significativos $(\mathrm{P}<0,05)$ para los diferentes atributos de germinación de semillas y crecimiento de plántulas. El acondicionamiento con poliaminas adelantó la germinación y sincronizó el porcentaje final de germinación, tiempo hasta $50 \%$ de germinación, tiempo medio de germinación, energía de germinación, velocidad de germinación, e índice de germinación en comparación con el control. El mejoramiento de longitud de tallo y raíz, peso fresco y seco de plántulas, tasa de crecimiento de plántulas y el índice de vigor de las plántulas fue claramente indicativo de los efectos positivos de la imprimación de semillas con poliamina. De todas las poliaminas, putrescina demostró ser mejor a bajas concentraciones (es decir 25 y $50 \mathrm{mM}$ ) 
para la mayoría de los rasgos relacionados con emergencia de semillas y crecimiento de plántulas.

Palabras clave: imprimación de semillas, Capsicum annuum, poliamina.

\section{LITERATURE CITED}

Afzal, I., F. Munir, C.M. Ayub, S.M.A. Basra, A. Hameed, and A. Nawaz. 2009. Changes in antioxidant enzymes, germination capacity and vigour of tomato seeds in response of priming with polyamines. Seed Science and Technology 37:765-770.

Amjad, M., and M.A. Anjum. 2002. Evaluation of physiological quality of onion seed stored for different periods. International Journal of Agriculture and Biology 4:365-369.

Andreoli, C., and A. Khan. 1999. Matriconditioning integrated with gibberellic acid to hasten seed germination and improve stand establishment of pepper and tomato. Pesquisa Agropecuária Brasileira 34:1953-1958.

Ashraf, M., and M.R. Foolad. 2005. Pre-sowing seed treatment - A shotgun approach to improve germination, growth and crop yield under saline and non-saline conditions. Advances in Agronomy $88: 223-271$

AOSA. 1983. Seed vigor testing hand book. Contribution $\mathrm{N}^{\circ} 32$. Association of Official Seed Analysis (AOSA), Springfield, Illinois, USA.

AOSA. 1990. Rules for testing seeds. Journal of Seed Technology 12:1-112.

Basra, A.S., B. Singh, and C.P. Malik. 1994. Priming-induced changes in polyamine levels in relation to vigor of aged onion seeds. Botanical Bulletin of Academia Sinica 35:19-23.

Cantliffe, D.J. 2003. Seed enhancements. Acta Horticulturae 607:5359.

Cvikrova, M., P. Binarova, V. Cenklova, J. Edera, and I. Machackova. 1999. Reinitiation of cell division and polyamine and aromatic monoamine levels in alfalfa explants during the induction of somatic embryogenesis. Physiologia Plantarum 105:330-337.

Demir, I., and G. Okcu. 2004. Aerated hydration treatment for improved germination and seedling growth in aubergine (Solanum melongena) and pepper (Capsicum annum). Annals of Applied Biology 144:121-123.

Ellis, R.H., and E.H. Roberts. 1981. The quantification of aging and survival in orthodox seeds. Seed Science and Technology 9:373409.

Farooq, M., S.M.A. Basra, K. Hafeez, and N. Ahmad. 2005. Thermal hardening: A new seed vigor enhancement tool in rice. Journal of Integrative Plant Biology 47:187-193.

Farooq, M., S.M.A. Basra, M. Hussain, H. Rehman, and B.A. Saleem. 2007. Incorporation of polyamines in the priming media enhances the germination and early seedling growth in hybrid sunflower (Helianthus annuus L.) International Journal of Agriculture and Biology 9:868-872.
Farooq, M., S.M.A. Basra, H. Rehman, and M. Hussain. 2008. Seed priming with polyamines improves the germination and early seedling growth in fine rice. Journal of New Seeds 9:145-155.

Farooq, M., T. Aziz, H. Rehman, A. Rehman, S.A. Cheema, and T. Aziz. 2011. Evaluating surface drying and re-drying for wheat seed priming with polyamines: effects on emergence, early seedling growth and starch metabolism. Acta Physiologia Plantarum 33:1707-1713.

Grassbaugh, E.M., and M.A. Bennett. 1998. Factors affecting vegetable stand establishment. Scientia Agricola 55:116-120.

He, L., K. Nada, and S. Tachibana. 2002. Effects of spermidine pretreatment through the roots on growth and photosynthesis of chilled cucumber plants (Cucumis sativus L.) Journal of Japanese Society of Horticultural Sciences 71:490-498.

Huang, H., and V.R. Villanueva. 1992. Amino acids, polyamines and proteins during seed germination of two species of Dipterocarpaceae. Trees Structure and Function 7:189-193.

Iqbal, M., and M. Ashraf. 2005. Changes in growth, photosynthetic capacity and ionic relations in spring wheat (Triticum aestivum L.) due to pre-sowing seed treatments with polyamines. Plant Growth Regulation 46:19-30.

Islam, A.K.M.A., N. Anuar, and Z. Yaakob. 2009. Effect of genotypes and pre-sowing treatments on seed germination behavior of Jatropha. Asian Journal of Plant Science 8:433-439.

Khan, H.A., C.M. Ayub, M.A. Pervez, R.M. Bilal, M.A. Shahid, and K. Ziaf. 2009a. Effect of seed priming with $\mathrm{NaCl}$ on salinity tolerance of hot pepper (Capsicum annuиm L.) at seedling stage. Soil and Environment 28:81-87.

Khan, H.A., M.A. Pervez, C.M. Ayub, K. Ziaf, R.M. Bilal, M.A. Shahid, and N. Akhtar. 2009b. Hormonal priming alleviates salt stress in hot pepper (Capsicum annuиm L.). Soil and Environment $28: 130-135$.

Kotowski, F. 1926. Temperature relations to germination of vegetable seeds. Proceedings of American Society of Horticulture Science 23:176-184.

Kusano, T., T. Berberich, C. Tateda, and Y. Takahashi. 2008. Polyamines: essential factors for growth and survival. Planta 228:367-381.

Pervez, M.A., C.M. Ayub, H.A. Khan, M.A. Shahid, and I. Ashraf. 2009. Effect of drought stress on growth, yield and seed quality of tomato (Lycopersicon esculentum L.) Pakistan Journal of Agricultural Sciences 46:174-178.

Srivastava, L.M. 2002. Plant growth and development: hormones and environment. Academic Press, London, UK.

Takahashi, T., and J. Kakehi. 2010. Polyamines: ubiquitous polycations with unique roles in growth and stress responses. Annals of Botany 105:1-6.

Wein, H.C. 1999. The physiology of vegetable crops. CAB International, New York, USA. 